\title{
The Adequacy of the Auditor's Report in the Anti-Graft Age: A Forensic View
}

\author{
Stanley Ogoun, Terry Keme Zuode Odogu \\ Department of Accountancy, Management Sciences, Niger Delta University, Wilberforce Island, Bayelsa State, Nigeria \\ Email: stanleyogoun@ndu.edu.ng, odoguterry@gmail.com
}

How to cite this paper: Ogoun, S. and Odogu, T.K.Z. (2020) The Adequacy of the Auditor's Report in the Anti-Graft Age: A Forensic View. iBusiness, 12, 13-32. https://doi.org/10.4236/ib.2020.121002

Received: January 2, 2020

Accepted: March 8, 2020

Published: March 11, 2020

Copyright $\odot 2020$ by author(s) and Scientific Research Publishing Inc. This work is licensed under the Creative Commons Attribution International License (CC BY 4.0).

http://creativecommons.org/licenses/by/4.0/

\begin{abstract}
One of the greatest evils ravaging the economies of developing and developed countries in the information age is financial crime with implications for the adequacy of the auditor's report. Therefore, this study is designed to qualitatively explore and interrogate available literatures, towards ascertaining whether the scope and content of audit and auditor's report meet the information needs and/or expectations of financial statement users in the anti-graft age, and to examine whether the conventional audit report can furnish anti-graft agencies with the required information that will enable them fight financial crimes. To achieve the above objectives, the quasi-judicial, credibility, inspired confidence and policeman theory of auditing were explored. Existing literatures revealed an expectation gap (in assurance and content) between auditors and financial statement users. Related literatures also suggest that conventional financial auditing tools and methods, especially audit sampling are not adequate to detect and prevent fraud and errors in the information age, and that the conventional audit report cannot meet the information needs of anti-graft agencies. The conclusion of the study is that conventional auditors, unlike forensic auditors, are mere watch-dogs and not blood-hounds, and as a result cannot proactively detect, prevent and investigate fraud. Consequently, it is recommended that forensic auditing should be deployed in corporate settings to peruse and investigate the facts behind the figures in reported corporate earnings as this would boost not only investors' confidence but the credibility of financial reports and that conventional auditors should acquire investigative skills and technology.
\end{abstract}

\section{Keywords}

Adequacy, Auditor's Report, Anti-Graft Age, Forensic Accounting

\section{Introduction}

The confidence and reverence reposed in the auditor's report in centuries back 
have been subjected to both public and scholarly contest and debate in the $21^{\text {st }}$ century. Many scholars have vehemently opposed this professional instrument of confidence and credibility. Worse still, even non-professional users of financial statements are increasingly becoming skeptic about the quality and reliability of the auditor's report. This is due to the insidious and ravaging plague of financial crimes that have eroded the elements that guarantee the going-concerns of business entities in the corporate world. This has led to many business failures and serious multiplier effects. Financial crimes are becoming more dynamic by the day complicated by enhanced e-payment platforms. Efforts by regulatory bodies, particularly the accountancy professional bodies seem to be futile. The work and the opinions of auditors cannot nip it in the bud. The expectations of the society are not met. This is because traditional audit tools were not crafted to meet evidence gathering requirements of the various criminal justice systems. Furthermore, prosecutorial evidence gathering was not the main purpose of audit. However, the ever increasing rate and complexity of financial crimes, associated with the dynamic nature of legal practice and interpretations of laws has greatly undermined the propriety of traditional audit in its context.

The fore has compelled governments of nations to aggressively intervene in both the public and private sectors of their economies, through the institution of special anti-graft agencies to investigate and prosecute perpetrators of financial crimes. The special intervention of government in the fight against financial shenanigans particularly in the private/corporate sector has thrown up a bundle of questions, which include:

1) How adequate is the content of the audit report to financial statement users?"

2) How adequate and appropriate are traditional auditing tools and techniques in the information age?

3) Can the report of auditors suffice the information need of anti-graft agencies in their fight against financial crime?

The auditing profession observed rightly that the primary duty of auditing is to examine financial statements and make opinion relative to their true and fair nature. Audit practitioners believe that the detection and prevention of fraud is secondary, and that auditors are not responsible to investigate fraud. They argue that fraud investigation is a responsibility that exceeds the current practice in audit profession and indeed beyond the scope and or bounds defined by the statues and professional standards. This observation is however contrary to the expectation of financial statement users [1]. In the same vein, a prior study by Nwaobial, Luke \& Theophilus [2], observed that many scholars are of the view that auditors should be bear responsibility for business failures, especially after the issuance of unqualified opinion in a financial year. This expectation mirrors the general perspective of all who rely on this information gate way to make decisions.

The above gap has led to the institution of anti-graft agencies with enabling legal framework in some jurisdictions to bridge the existing expectation gap be- 
tween auditors and financial statement users. Anti-graft agencies according to Nwokorie \& Viinamäki [3] are arm's length bodies of government or quangos instituted to proactively and independently fight financial crimes. Due to the perceived inadequacies of financial audit reports, anti-graft agencies rely on forensic experts for evidence. Thus, Ehioghiren \& Atu [4] discovered a significant difference between the duties of professional forensic auditors and that of traditional external auditors in fraud detection and investigation, and concluded that forensic accounting is an effective tool in uncovering diverted fraudulent practices and misappropriated assets. In the light of the above, Peter, Jerry \& Danjuma [5] proposed that since the external audit is not effective in revealing fraud, governing statutes should be amended to inculcate forensic audit.

This study is therefore designed to qualitatively explore available literature and theories to explain and expose why and how the conventional traditional audit and its report is no longer adequate and reliable in the detection and prevention of fraud and error. It is further designed to expose the need and advocacy for anti-graft agencies and forensic approach to audit, as the panacea to the audit expectation quagmire between external auditors and the public.

\section{Literature Review}

From the scholarly works of Tandon, Sudharsanam \& Sundharabahu [6]; Beatline [7]; Kantudu [8], and International Auditing Guidelines (IAGs), audit can be succinctly defined as the critical and intelligent evaluation of a set of financial statements, system, process, project and product of an enterprise, by an appointed qualified and professional accountant, in order to give an expert opinion, certificate, attestation or advice. The primary objective of auditing, according to Peter, Jerry \& Danjuma [5] is to express professional opinion on the truth and fairness of the financial statements examined by the auditor, in order to guide or give confidence to users of financial statements. Beside the primary objectives which practitioners argue is their concern, is the secondary objective of detection and prevention of fraud and errors, and provision of other accounting services to audit clients [9]. The PCAOB Chairman asserted in 2004 that, "detecting fraud is the responsibility of external auditors and that with few exceptions they should find it". Current auditing standards also expect auditors to obtain reasonable assurance that financial statements taken as a whole are free from material misstatement due to fraud (PCAOB 2010; IAASB 2009, PCAOB 2002; AICPA 2002).

However, Ajao, Olamide, \& Temitope [10] posited that the secondary objective of cross-selling of other accounting services to audit clients, can constitute a threat to the independence of the auditor, given the collapse and bankruptcy of Arthur Anderson and Enron Corporation of America in 2001 and 2002. Arthur Anderson, one of the biggest audit and accountancy partnerships in America compromised and traded off its independence and the quality of its opinion in pursuit of the secondary objective of auditing, and this led to the emergence of an anti-graft law called the Sarbanes-Oxley Act. 
Thus, gleaned from the definitions and explanations of auditing (above), the gap in expectations is quite obvious. This gap, no doubt is contingent upon the scandals and well based on society's expectation that haven evaluated the accounts and provided an affirmative opinion, auditors should take responsibility for any unpleasant outcome from reliance on the audited reports.

\subsection{The Auditor and His Responsibility in the $21^{\text {st }}$ Century}

The age long questions revolving around the responsibility of auditor are: Is the auditor appointed just to make professional opinion? Is the opinion of the auditor adequate? If auditors are only expected to concentrate on documentary or physical evidence which is not adequate to unveil corrupt evidence and systematic (managerial) fraud, who then should detect and prevent fraud and errors? The Society, especially users of financial statements have a broader view of the responsibilities of the auditors and the quality of their report. In the opinion of the society, the discovery and prevention of fraud is incumbent on auditors. Hence, Peter, Jerry \& Danjuma [5] opined that the role of auditors in modern times has gone beyond the mere examination and certification of financial statements in respect to their truth and fairness. They argued that auditors have a duty to assure investors that the financial statements of an organisation are free from fraud and other irregularities.

Dyck, Morse \& Zingales [11] also agreed that, "external auditors have a significant role to play in the detection and prevention of fraud because they are not only agents of the shareholders but their access to internal and external information makes them efficient monitors". In the light of the above, Salehi [1] asserted that assurance statements address critical questions like: does this report give an account of the company and its performance on which readers can rely? Is the report complete, accurate, honest and balanced in its portrayal of the organisation? Hence, Peter, Jerry \& Danjuma [5] concluded that by virtue of duty, the auditors are supposed to serve as watchmen on behalf of management, shareholders and the entire society. Previously, Hooks [12] had vehemently remarked that the auditing profession has over the years refused to assume responsibility to investigate, detect and prevent fraud, and this is responsible for the expectation gap.

Obviously there is an audit expectation gap between auditors and financial statement users relative to the auditors' duties and responsibilities and the messages conveyed by audit reports [13] [14] [15] [16]. This is widened by corporate failures and bankruptcies as evident in the scandals of Enron, WorldCom, Texaco, etc. Thus, Salehi [1] asserted that every business failure is associated with audit failure, regardless of the level of procedures and tests performed by the auditor. Likewise, scholars such as [17] [18] seriously queried the audit profession's self-regulation and over-protection of self-interest and concluded that audit expectation gap is caused by the controversial philosophy of the audit profession about the responsibility of auditors. This disagreement calls for a test of the adequacy, reliability, sufficiency and quality of the auditor's report. It further 
calls for a brief perusal of relevant auditing theories in the light of the much-quoted statement by Humphrey [19] as to whether the auditor is "a watch-dog or a bloodhound".

Accordingly, the responsibility of the auditor is viewed from two different perspectives, namely; the professional and public interest angles, thereby creating a gap that calls for theoretical justifications, in the determination and judgement of audit quality.

\subsection{Auditing Theories and Audit Quality}

1) Quasi-Judicial Theory. This theory claims that the auditor is a judge in the financial distribution process, and as such is considered as the last hope of shareholders and other financial statement users [20]. Conversely, Porter [21] remarked that unlike a judge, the doctrine of precedence and consistency is not guaranteed in auditing, and that the auditor's independence differs from a judge's independence because of the different reward system involved. However, if the auditor can say that a set of financial statements represent the true situation of a company and are fair, is he not a judge? The deposition here is that the audit opinion is the final pronouncement required on financial statements as being credible and thus should be relied upon by all. This view is well collocated with the statutory requirements of publicly quoted companies.

2) Credibility Theory: This theory is premised on the conflicting interests in the agency theory. It thus proposes that the primary function of auditing is to enhance shareholder's (principal's) confidence on the stewardship assignment of managers (agents), and to reduce the information asymmetry [1] [20]. However, Porter [21] argued that there are numerous users of financial statements, and suggested that for adequacy and reliability, audit must not be considered as an exercise not only makes financial statements appear credible before shareholders, but a painstaking and thorough exercise that allays the fears of prospective investors and other users of financial statements.

3) Theory of Inspired Confidence: Hayes et al. [20] and the proponent of this theory, Limperg (1920) believe that the participation of outside stakeholders in a company depends on reliable audit services, because information provided by management might be biased. This theory is thus, premised on the suspicion that information provided by managers are inadequate, and that only information (report) given by an auditor can be adequate and reliable. The theory therefore, expects the auditor to execute his job in a professional manner that would meet reasonable public expectations, which of course, is the agitation and expectation of the public.

4) Policeman Theory: This was very popular and widely accepted until the 1940s. The policeman theory claims that the auditor is a policeman and as such should focus on the arithmetical accuracy of financial figures and records. It thus expects the auditor to prevent and detect fraud [20], which again is the argument of financial statement users. However, it suggests that auditors are watch-dogs, but not blood hounds. 
Evidently from the theoretical submissions, it is clear that the preponderance of opinion is in favour of audit combining both roles of being a watch-dog as well as a blood hound. Audit is a creation of society and its continued relevance is a function of meeting society's expectation. Thus, it incumbent on the audit professional to give up its traditional role and embrace the much wider role arising from societal expectation. Society itself is dynamic and not static and therefore audit cannot remain in its traditional defined role. The character of human economic transaction is changing and human greed appears to be on the rise thus foreclosing the traditional held strong views of morality and contentment. This greed propelled behaviour is leading to primitive acquisition and so called smart actions within a globalized personal acquisition world frame. Respect in society within human social interactions is increasingly be defined by wealth and even the might of nations is defined by economic power, thus creating an enabling environ for so called smart wealth acquisition models that often negate the norms of morality and even national laws.

Hence, the appropriateness of the different theories discussed can only be determined by the auditor's report. For instance, is the auditor's report a verdict, is it credible, does it inspire public confidence or is it just a policeman's/watchman's report? On these theoretical espousals is the current research collocated. As all the theories find relevance in providing narrative perspectives to the audit function, bearing mind stake holders' expectations.

\subsection{The Auditor's Report}

The auditor's report is prepared according to accepted standards established by governing bodies, such as the Financial Reporting Council of Nigeria (FRCN), UK Generally Accepted Accounting Practice (UK GAAP), Australian Auditing and Assurance Standards Board (AuASB), European Organisation of Supreme Audit Institution (EUROSAI), International Organisation of Supreme Audit Institution (INTOSAI), International Auditing and Assurance Standards Board (IAASB). There are four types of audit reports or opinions, which can be broadly classified into two:

1) Unqualified or Clean Report. This is issued when an auditor is satisfied in all material respects that enables him to express the required opinion on the financial statements without any reservations. It thus, a report that concludes that the financial statements give a true and fair view in accordance with the relevant financial reporting framework.

2) Modified Report or Non-Standard Report. This is issued when there is a misstatement about the treatment or disclosure of a matter in the financial and/or non-financial information; or there is a limitation in the scope of an audit. It occurs when an auditor is unable to obtain sufficient appropriate evidence to support and express an opinion on (a part or the entire) financial or non-financial information. There are three types of modified or non-standard opinions:

Adverse Opinion: This is the most serious type of non-standard audit report. An adverse opinion is expressed when an auditor, having obtained sufficient ap- 
propriate audit evidence, concludes that misstatements, individually or in the aggregate, are both material and pervasive to the financial and/or non-financial information.

Disclaimers of Opinion: This is expressed when an auditor is unable to obtain sufficient appropriate audit evidence on which to base the opinion (that is, a limitation in scope), and the auditor concludes that the possible effects on the financial and/or non-financial information of undetected misstatements, if any, could be both material and pervasive. It is also expressed when, in extremely rare circumstances involving multiple uncertainties, an auditor concludes that it is not possible to form an opinion on the financial statements and/or non-financial performance information because of the potential interaction of the uncertainties and their possible cumulative effect on the financial and/or non-financial information.

Qualified Opinion: This is expressed when the appointed auditor, having obtained sufficient appropriate audit evidence, concludes that misstatements, individually or in aggregate, are material, but not pervasive, to the financial and/or non-financial information.

The auditor's report contains the Name of the audited company, and its accounting method; the responsibility of the auditor; reservations (if any); conclusion; any additional information*; a management report ${ }^{*}$; the date and auditor's signature. The content of the auditor's report indicates that the auditor's report is not voluminous. It is very precise and does not explain or give details of the findings and/or observations of the auditor. Furthermore, there is no clause of assurance, responsibility, accountability or liability by the auditor. This is contrary to the expectation of the public (society) and does not seem to be adequate to allay the doubts and fears of an unprofessional user of financial statements.

Many users misunderstand the nature of the attest function, especially in the context of an unqualified opinion. Even with the understanding of the word "unqualified", some users believe that an unqualified report implies that the audited firm has a clean-proof financial reporting. A clean (unqualified) report may be issued with respect to materiality, which is a concept that measures degree and level of effect. Materiality is a concept that is influenced by both quantitative (numerical) and qualitative factors [5]. Thus, a set of financial statements can be claimed to be true and fair when they are free of material misstatements

Evidently, the type, content and language of the auditor's opinion, determine the quality and adequacy of the auditor's report and implications for public confidence.

\subsection{Audit Quality and Adequacy}

Audit quality according to DeAngelo [22] is the probability that the auditor will uncover and report a breach. He therefore opined that, except an auditor is objective, he is less likely to report irregularities, thereby impairing audit quality. This suggests that audit quality is a function of auditor's independence and ex- 
pertise. However, in the words and works of Palmrose [23]; Davidson \& Neu [24], audit quality can be equally viewed as the ability of an auditor to identify and bring to light material misstatements and manipulations in the financial statements. Similarly, Salehi \& Azary [25] opined that audit quality is the ability of the auditor to protect the interest of users by detecting and reporting material misstatements in financial statements and reducing information asymmetry between management and users of financial statements. Drawing from the philosophy of Salehi \& Kangarlouei [26], audit quality can be further viewed as the concern of financial statements users over the reliability and or adequacy of the audit report, as they cannot personally or directly assess or ascertain audit quality.

However, Brazel, Jones \& Zimbelman [27] claimed that the analytical procedures of the external auditor which revolves round statistical sampling obscure the vision of auditors in their mission of fraud detection and prevention and as such are ineffective. They further asserted that external auditors most often rely on management's explanations without adequately testing their validity, and that these auditing improprieties have resulted to unpleasant errors, fraud, and misstatements. Consequently, Olofin [28] and Agbaje [29] have called the competence, skills, due care, honesty, and integrity of auditors to question. On this back-drop, Bies (2004) recommended greater responsibility and increased scrutiny in the auditing profession.

The quality of an audit, according to Yuniarti [30] depends on satisfactory answers to a bundle of questions, such as: what importance is attached to the audit? Is the findings by the auditor a true representation of the affairs of the audited entity or is management claims about the company accurate? What level of independence was displayed during the course of the audit? Was the entire length and breadth of the audit duly covered? What is the minimal audit delay in presenting report? Was the audit work done well communicated in terms of findings and recommendations? Was the cost incurred in the exercise tangent with the benefits accrued? Where the objectives of the audit achieved?

The reliability or better still adequacy of an audit report according to the NBA Practice Note [31] and other authorities, is a function of many other factors such as:

1) Input: One of the factors that determines the quality of an audit report is investment in staff, time available for audit engagements, technology and methodology. This is because "the output of a process is the result of its input" (garbage in garbage out).

2) Process: This entails the involvement and consultation of specialists and regular review for quality, to monitor and build safeguards in the audit process to monitor and secure the quality of audit conducted. It thus entails compliance and independence checks and tests, as well as spending quality time with IT specialists and other specialists on audit engagements.

3) Output: Beside the above measures, audit firms are expected to deeply consider the number of internal and external quality reviews conducted after the issuance of the audit report, as a percentage of the total number of issued audi- 
tor's reports, and the outcome of these quality reviews. Audit firms are further required to ascertain the number of internally reported violations of independence rules, as a percentage of the total number of employees. A critical look at the number of fundamental errors made and corrected, as a percentage of the number of reports issued by the firm is also key to audit quality.

4) Client Importance: Although, there is mixed empirical evidence according to Tepalagul \& Lin [32], there is a school of thought that says audit firms are economic entities, and as such can hallow economically viable clients and give them greater weight in their portfolio. It is perceived that, auditors have a higher incentive to yield to pressure from economically viable clients to compromise their independence and objectivity.

5) Auditor Size: Although Enron Corporation acted contrary, DeAngelo [22] opined that the size of an audit firm can positively affect the quality of audit report. This is because big audit firms have their name, integrity and goodwill to protect, and are financially buoyant to train their staff, consult specialists and employ modern facilities and technology in auditing.

6) Auditor's Tenure: There is a school of thought that says, "as the auditor-client relationship lengthens, the tendency for the auditor to undermine standards and act in favour of management becomes inevitable". According to the other divide, "as the auditor's tenure lengthens, he becomes more conversant with the accounting system and nature of his client's business and therefore has more experience to bring his professional expertise to bear. While the former advocates for mandatory partner rotation, the latter believes in continuous engagement. However, can't the continuous engagement of an audit firm make it appear like an employee?

7) Non-Audit Services. Although some professionals argue that the joint provision of audit and NAS increases auditors' knowledge base and may result in a more efficient and effective audit, the SOX Act is premised on the belief that the resulting economic bond between auditors and clients would impair auditors' independence, thereby compromising audit quality and report.

8) Auditor's Employment and Related Incentives. Evidences from the works of Imhoff [33]; Lennox [34] and Ye, Carson \& Simnett [35] suggest that client-auditor employment relationships are more likely to compromise the independence, integrity and quality of auditors and their report.

9) Client's Affiliation with Audit Firms. Although, Francis [36] saw limited evidence on affiliation threat, Imhoff [33] vehemently argued that client's-auditor cordial relationship can separate the auditor from shareholders (who appointed him), which can significantly impair the auditor's report and independence.

10) External Supervision: Regulatory bodies in accordance with the Audit Firms Supervision Decree in Dutch require all audit firms to draw up a report within three months of the completion of their financial year, stating their legal, organisational, network and quality control evaluation structure; number of public interest entities audited during the year, as well as information about the 
grounds for remuneration of the external auditors.

11) Publication of Audit Report. Dutch audit firms are further required by law to sign and post their audit reports to their websites, and keep the reports posted and accessible on the websites for at least one year.

12) Transparency Report. The Audit Firms Supervision Act of Netherlands and EU expect all audit firms to sign and publish Annual Transparency Report on their websites with certain information under general management measures. Such reports can only be updated upon the communication to and approval of and by competent authorities, with a statement that it is an updated version of report.

The above checklists implies that audit must not be seen as a mere compliance with statutory requirement, but the audit report is presented concisely and professionally. The audit report is drafted in the accounting parlance which the average reader (user) cannot fully understand without the help of an analyst. The concise nature of the audit report does not meet the public and financial statements users' definition of adequacy. The current auditor's report is often perceived by users of financial statements as not providing meaningful insights or information of value [2]. Many scholars [37] [38] [39] [40] have doubted the usefulness of audit report to users of financial statements and have asked questions such as: does this report give an account of the company and its performance on which readers can rely? Is the report complete, accurate, honest and balanced in its portrayal of the organisation?

In response to the identified inadequacies, the International Auditing and Assurance Standards Board (IAASB, 2015) has proposed a new and revised Auditor Reporting Standards, for (better) global auditor reporting and communication. The new Auditor Reporting Standards are responsive to the call for a more informative and relevant audit report from investors and other users of audited financial statements. Nwaobia, Luke, \& Theophilus [2], have affirmed that the new requirements are adequate and could be a sufficient response to the expectation gap (earlier discussed).

However, for audit reports to be adequate in content and quality, greater regulation, monitoring and periodic evaluation by professional bodies and even governments of nations is not only necessary but expedient. Arguably therefore, the quality of and adequacy of an audit report is hinged on the variables outlined in the literature, but as to whether the presence of this attributes provide a sufficient basis for litigation via evidence tendering to sway judgment is the gap that has necessitated the incursion of forensics.

\subsection{The Emergence of Anti-Graft Agencies and Forensic Accounting}

The inadequacy in the detection and prevention of fraud and errors, and the continuous increase in corruption have made governments of countries introduce special anti-graft agencies [3]. This is evident in Table 1 below. 
Table 1. List of countries and anti-graft agencies.

\begin{tabular}{|c|c|}
\hline Country & Anti-graft Agencies \\
\hline Australia & $\begin{array}{l}\text { Crime and Corruption Commission, Independent Broad-based } \\
\text { Anti-corruption Commission (IBAC) }\end{array}$ \\
\hline Cameroun & National Anti-Corruption Observatory \\
\hline China & $\begin{array}{l}\text { National Supervisory Commission, Central Commission for Discipline } \\
\text { Inspection }\end{array}$ \\
\hline India & Central Vigilance Commission \\
\hline Indonesia & Corruption Eradication Commission \\
\hline Kenya & Ethics and Anti-corruption Commission \\
\hline Liberia & Anti-Corruption Commission \\
\hline Malaysia & Anti-Corruption Commission \\
\hline New Zealand & Serious Fraud Office \\
\hline Nigeria & $\begin{array}{l}\text { Code of Conduct Bureau (CCB), Code of Conduct Tribunal (CCT), } \\
\text { Economic and Financial Crimes Commission (EFCC), and Independent } \\
\text { Corrupt Practices and Other Related Offences Commission (ICPC) }\end{array}$ \\
\hline South Africa & National Anti-Corruption Forum \\
\hline United Kingdom & Corruption Watch, Serious Fraud Office \\
\hline Zimbabwe & Anti-Corruption Commission \\
\hline
\end{tabular}

Source: $7^{\text {th }}$ Anti-Corruption agency forum, Wikipedia (2013).

These agencies are set up to formulate and ensure a sound legal framework and financial management, as well as to investigate and prosecute financial crimes (fraud) and perpetrators. Financial crime is becoming a global phenomenon and network, and is even getting out of the control of national anti-graft agencies. As a result, international anti-graft agencies such as the Global Anti-Corruption Coalition and the International Anti-Corruption Coordination Centre (IACCC) are currently bridging the inadequacies of national agencies by creating a constructive, collective and cooperative global law enforcement system. Thus, the IACCC is poised to collect information to form a single picture of grand corruption, as well as ensure fast-time intelligence sharing; assist countries that have suffered grand corruption and help bring corrupt elites to justice.

The burning questions are: "can the above institutions rely on audit reports? Can they gather sufficient evidence from auditors of firms and government institutions? The single answer to these questions seems to be 'NO'”. Hence, the emergence of "forensic accounting". Forensic accountants work with the URL of a list of key international organisations to obtain adequate and quality information to investigate financial anomalies in order to provide reliable evidence for legal proceedings and/prosecution. International anti-graft agencies that relate with forensic accountants include: Association of Certified Fraud Examiners (http://acfe.com); American College of Forensic Examiners (http://www.acfei.com); Association of Certified Fraud Specialists (http://www.acfsnet.org); National Liti- 
gation Support Services Association (http://www.nissa.com); National Association of Certified Valuation Analysts (http://www.nacva.com); American Institute of Certified Public Accountants (http://www.aicpa.org); and The Institute of Business Appraisers (http://www.go-iba.org).

Forensic accounting, the brain-child of Kenneth W. Robinson was first instituted by Maurice E. Peloubet in 1946 [41]. It is interchangeably called forensic auditing, investigative accounting or financial forensics. However, in the context of this study, it is referred to as "forensic auditing". Forensic auditing according to Bologna \& Lindquist [42] is, "the application of financial skills, and an investigative mentality to unresolved issues, conducted within the context of rules of evidence”. The American Institute of Certified Public Accountant [43] defined it as, "the application of accounting principles, theories, and discipline to facts or hypotheses at issues in a legal dispute and encompasses every branch of accounting knowledge." It is further considered as, "the science that deals with the application of finance, accounting, tax and auditing knowledge to analyse, investigate, inquire, test and examine matters in civil law, criminal law and jurisprudence in an attempt to obtain the truth from which to render an expert opinion" [44]. Forensic auditing is therefore a blend of accounting, auditing and investigative skills.

Forensic auditing reconciles the professional and knowledge gaps between traditional auditing and contemporary audit expectations. It is a new sub-discipline in the accounting profession that seeks to determine whether accounting transactions are in consonance with various accounting, auditing and legal requirements, and eventually determine whether any fraud has taken place. Forensic auditing therefore emerged to meet the obvious inadequacies of conventional audit report. In this regard, Imomana, Antunes \& Formigoni [45] concluded that, the emergence of forensic auditing is premised on the reality that conventional (financial) auditing cannot effectively investigate and detect frauds.

This suggests that, for audit reports to be adequate and reliable, auditors need further forensic training. From the works of Wells [46]; Kleeyman [47]; DiGabriele [48]; Crawford [49], and Zia [44] forensic auditing requires: persistence and firmness; knowledge aptitudes in criminology, computer abilities, confidence/composure, curiosity, creativity, discretion, prudence, secrecy, honesty, personal strength, deductive analysis, critical thinking, unstructured problem solving, investigative flexibility, analytical proficiency, oral communication, written communication and specific legal knowledge.

From the above assertions, one can infer that there is a difference between conventional auditing and forensic auditing. Below is a table showing the difference between conventional auditing and forensic auditing (Table 2).

From the contents of Table 2, one can deduce that forensic auditing is more detailed and thorough than traditional/conventional external auditing. Again, forensic auditing is both reactive and proactive, but traditional auditing is merely reactive. Consequently, while conventional auditors are best described as watch-dog, forensic auditors are blood hounds. This answers the question of Humphrey [19] 
Table 2. Distinction between the conventional (external) auditor \& forensic auditor.

\begin{tabular}{|c|c|}
\hline Conventional (External) Auditor & Forensic Auditor (Accountant) \\
\hline Audit is carried out by external auditors. & Audit is carried out by forensic auditors. \\
\hline $\begin{array}{l}\text { Possesses the normal accounting } \\
\text { knowledge and professional training. }\end{array}$ & $\begin{array}{l}\text { Possesses additional (investigative) } \\
\text { training and skills in addition to the } \\
\text { normal accounting knowledge } \\
\text { and professional training. }\end{array}$ \\
\hline Acts like a watch-dog. & $\begin{array}{l}\text { Acts like a blood hound-hound for } \\
\text { conclusive evidence. }\end{array}$ \\
\hline Acts reactively. & Acts proactively and reactively. \\
\hline $\begin{array}{l}\text { Primarily out to make an opinion on } \\
\text { financial statements, and detect and } \\
\text { prevent fraud where necessary. }\end{array}$ & $\begin{array}{l}\text { Primarily out to investigate and expose } \\
\text { fraud and criminal transactions. }\end{array}$ \\
\hline $\begin{array}{l}\text { Examines income statements, statement } \\
\text { of financial position, cash flow statements } \\
\text { and related financial records. }\end{array}$ & $\begin{array}{l}\text { Examines manufacturing account, } \\
\text { income statements, statement of } \\
\text { financial position, directors'/auditor's } \\
\text { reports. Examines related party } \\
\text { transactions and inter-corporate deposits. }\end{array}$ \\
\hline Limits audit to components of financial statements. & $\begin{array}{l}\text { Carries out cost audit, off balance sheet } \\
\text { items audit \& comparative analysis of } \\
\text { financial statements. }\end{array}$ \\
\hline Finds out deliberate misstatements only. & Finds out the misstatements deliberately. \\
\hline $\begin{array}{l}\text { Looks at only the numbers } \\
\text { (all things being equal, takes numbers as they are). }\end{array}$ & $\begin{array}{l}\text { Looks beyond the numbers } \\
\text { (investigate numbers and figures). }\end{array}$ \\
\hline $\begin{array}{l}\text { Carries out audit within the scope of } \\
\text { engagement letter, and in accordance with the } \\
\text { entity concept in accounting and corporate law. }\end{array}$ & $\begin{array}{l}\text { Pierces the veil of corporate entity } \\
\text { (where necessary) to establish } \\
\text { the intentions of person(s) behind } \\
\text { suspicious transaction(s). }\end{array}$ \\
\hline $\begin{array}{l}\text { Standards are set by professional } \\
\text { and/or regulatory bodies. }\end{array}$ & Standards evolve from courts of law. \\
\hline
\end{tabular}

Source: Authors' Compilation from Joshi [41]; Kleeyman [47]; Digabriele [48]; Gray [50]; Dyck, et al. [11].

who asked whether the auditor is a blood-hound or watch-dog. Furthermore, forensic auditing has a stronger legal framework that is specially designed and supported by the governments of nations, to deliberately investigate, prosecute and reduce financial crimes. It can therefore be established that forensic auditing is an efficient and effective tool against corporate fraud. The frequent utilisation of forensic audit services according to Enofe \& Omagbon [51] would significantly help in the detection and prevention of financial shenanigans especially in the corporate world.

The above distinctions between conventional auditing and forensic auditing are empirically reflected in the light of detection and prevention of fraud and error, by scholars from 2001 to 2019 below:

\subsection{Empirical Argument for Forensic Auditing}

Quite a number of scholars have advocated for forensic auditing in the discussion of audit expectation gap and audit quality. For example, Apostolou, et al. 
[52] posited that forensic accounting is an aspect of accounting that offers the highest level of assurance. Similarly, Krell [53] opined that forensic accounting is detailed enough to penetrate and detect concealed facts. Moreover, Moyes \& Bakers [54] argued that auditors' high skilled knowledge of forensic accounting is most likely to detect and prevent fraud in companies. The works of Hemraj [55]; Apostolon \& Crumbley [56]; Houck, Krancher, Morris, Riley, Jr., et al. [57]; Bhasin [58] and Skousen \& Wright [59] all point to the fact that forensic auditing is evidentiary in nature and is designed for fact finding towards the detection of financial misrepresentation or fraud and errors.

Krstic [60] states that forensic accounting is a generally accepted accounting technique for securing reliable financial statements. Against this backdrop, Singleton \& Singleton [61] remarked that forensic accounting is a comprehensive accounting technique that prevents fraud and analyse antifraud control. Islam, Rahman \& Hossan [62] in their work titled, "forensic accounting as a tool for detecting fraud and corruption: an empirical study in Bangladesh" found that forensic accounting is a critical tool in the fight against corruption, detection and prevention of fraud in Bangladesh. A similar study carried out in Nigeria by Adegbie \& Fakile [63] revealed that forensic accounting is a financial strategy to curb and resolve economic and financial crimes in the Nigerian economy. It further revealed that forensic accounting will institute and instill good corporate governance and public confidence in auditing.

In the light of the above, Gbegi \& Adebisi [64] adduced that forensic accounting skills and techniques are significantly related to fraud detection and reduction. Hence, Augustine \& Uagbale-Ekatah [65] suggested that frequent utilization of forensic audit services will significantly help in the detection, prevention and reduction of fraud. Amake \& Ikhatua [66] uniquely did a study on "forensic accounting and fraud detection in Nigerian public sector" and discovered that the application of forensic accounting in the Nigerian public sector is effective in detecting fraud. In 2018, Rehman \& Hashim [67] found that forensic accounting is best positioned to stamp out corporate governance fraud risk, hence, forensic accounting has a positive association with corporate governance maturity, while in 2019, Oyedokun [68] documented that forensic accounting practice can deter individuals from fraud and money laundering. All in all, it can be inferred that forensic approach to auditing would greatly reduce the shortcomings and loop-holes in conventional auditing, and therefore bridge the audit expectation gap between auditors and the public.

\subsection{Summary of the Literature}

There has been an age long debate over the role and responsibility of the auditor. While the auditor argues that his professional and primary role in any audit assignment is to examine the financial statements, records and books presented before him and make an independent professional opinion as to whether they are prepared according to generally accepted accounting principles and standards, and not necessarily to detect and prevent fraud and error, the public is of 
the opinion that the auditor must prioritize the detection and prevention of fraud in his audit assignment. This has created an expectation gap between auditors and financial statement users, and is indeed, the motivation of this study, as it seems to question the adequacy and reliability of the auditor's report.

A number of scholars, Sikka et al. [17], Giacomino [18] and Chandler \& Edwards [69], Dyck, Morse \& Zingales [11], Salehi [1] and Peter, Jerry \& Danjuma [5] have expressed opinion in favour of the argument of the public, that a statement of assurance that the financial statements are free of frauds and errors is necessary to alley the fear and suspicion of the public. However, the accounting and auditing profession is yet to explicitly review and modify the scope and responsibility of the auditor. Related theories consulted suggest conflicting views. The quasi-judicial and policeman theories seem to suggest that the auditor's report and responsibility as prescribed by the auditing profession is adequate, reliable and justifiable. Contrarily, the credibility and inspired theories both argue that auditing should not be a mere examination of financial statement but a painstaking and thorough exercise that should guarantee the confidence of the public.

There are different types of audit report which are broadly classified into unqualified and qualified opinions, with different meanings, but they appear too brief and professional in content and language to the public. DeAngelo [22], Palmrose [23], Davidson \& Neu [24] and Salehi \& Azary [25] related the quality of the auditor's report to the ability of the auditor to protect the interest of the public. Similarly, Imboff [33]; Lennox [34]; Ye, Carson \& Simnet [35]; Tepalagul [32] and the NBA Practice Note [31] outlined twelve conditions for judging the adequacy, reliability and quality of the auditor's report. Perceived gap between the auditor's report and the public expectation has led to the establishment of anti-graft agencies; and this has further led to the emergence of forensic accounting. This is an off-shoot of conventional auditing which according to Enofe \& Omagbon [51] is proactively designed to detect and prevent financial shenanigans, in the interest of the public.

\subsection{Research Findings}

Available literature and theories consulted reveal that:

1) The professional definition of auditing does not see the detection of fraud and error as the primary objective of auditing.

2) The public is suspicious of managers of firms and is therefore more interested in the detection of fraud and error in auditing.

3) Auditors are mere watch dogs (policemen) and not blood hounds.

4) The public is not always confident of the auditor's report.

5) The auditor's report is too brief and professional in language.

6) The public and scholars are advocating for forensic auditing.

7) Forensic auditing is primarily designed for the detection and prevention of fraud and error and would bridge the expectation gap in auditing. 


\section{Summary, Conclusions and Recommendations}

This study was construed towards a theoretical review of the existing literature, to glean meaning and anchor whether, in its traditional form, the auditor's report is adequate in this anti-graft age where audit evidence gathering for prosecutorial purposes has been accentuated. Thus, theoretical evidence gleaned from the conceptual construct, and interrogation of the existing literature, provides the foundation for the conclusion reached herein.

The professional objective of auditing does not lay emphasis the detection, prevention and investigation of fraud. Hence, conventional audit report is not adequate in the eyes of the public. Secondly, conventional auditors perform their audit function within the scope of audit engagement and in line with the entity concept of accounting. They are not blood-hounds but mere watch-dogs. Hence, may not satisfy suspicious users of financial statements, especially anti-graft agencies. Thirdly, conventional financial audit report is very concise and is drafted in line with the accounting parlance. It is neither explanatory nor simple to the average non-professional user. Therefore, the content of the audit report does not adequately address the information needs of the average financial statement user. Furthermore, the extensive use of sampling and the resultant effects of errors and misstatements had called the report of conventional audit to question and serious test. Thus, conventional financial auditing tools and methodologies are fast becoming outdated and too weak to stand the test of the information age. In conclusion, the conventional audit report is no longer adequate in the $21^{\text {st }}$ century, because "adequate audit report (AAR) in the anti-graft age is a function of many variables such as, auditor's independence (AID which is a function of audit fee, other services, owner's interest, etc.); information and communication technology (ICT), and forensic auditing skills (FAS). Also, the nature of audit evidence required for prosecutorial purposes can be addressed within the framework of the traditional role function, as evidenced in the inability of persecutors to successful adduce financial crime evidence for litigation purposes.

It is therefore recommended that, regulatory bodies should redefine the scope, objectives and responsibilities of conventional audit to address the concerns of financial statement users. Secondly, audit firms should transparently publish their audit report on their websites, and should be properly regulated in their provision of other professional (accounting) services to their audit clients. Thirdly, professional bodies should embark on regular training of members especially in IT and electronic auditing and the use of computer assisted auditing techniques (CAATs). Above all, governments of nations should institutionalize forensic audit as a separate audit service, and forensic auditors should check and investigate conventional (external) auditors for the professional negligence and misconduct.

\section{Conflicts of Interest}

The authors declare no conflicts of interest regarding the publication of this paper. 


\section{References}

[1] Salehi, M. (2011) Audit Expectation Gap: Concept, Nature and Trace. African Journal of Business Management, 5, 8376-8392. https://doi.org/10.5897/AJBM11.963

[2] Nwaobia, N.A., Luke, O. and Theophilus, A.A. (2016) The New Auditors' Reporting Standards and the Audit Expectation Gap. International Journal of Advanced Academic Research: Social and Management Sciences, 2, 118-133.

[3] Nwokorie, E.C. and Viinamäki, O.-P. (2017) Legitimacy Building of Anti-Corruption Agencies in Five Countries. OECD Global Anti-Corruption \& Integrity Forum, Paris, 30-31 March 2017, 1-14.

[4] Ehioghiren, E.E. and Atu, O.O.K. (2016) Forensic Accounting and Fraud Management: Evidence from Nigeria, Igbinedion University. Journal of Accounting, 2, 245-301.

[5] Peter, Z., Jerry, M. and Danjuma, I. (2012) Assessment of the Adequacy of External Auditing in Disclosing Fraud in Nigerian Commercial Banks. Research Journal of Finance and Accounting, 3, 149-156

[6] Tandon, B.N., Sudharsanam, S. and Sundharabahu, S. (2006) A Handbook of Practical Auditing. 13th Edition, S. Chand and Company Limited, New Delhi.

[7] Beatline, A. (1992) What Is an Audit? The Nigerian Accountant, 25, 41.

[8] Kantudu, A.S. (2004) The Relevance of Auditor's Report in Enhancing Management Accountability in Nigeria.

[9] Adeniji, A.A. (2004) Auditing and Investigations. El-Toda Ventures Ltd., Lagos.

[10] Ajao, O.S., Olamide, J.O. and Temitope, A.A. (2016) Evolution and Development of Auditing. Unique Journal of Business Research, 3, 32-40.

[11] Dyck, A., Morse, A. and Zingales, L. (2008) Who Blows the Whistle on Corporate Fraud? http://www.ssrn.com https://doi.org/10.2139/ssrn.891482

[12] Hooks, K.L. (1992) Professionalism and Self-Interest: A Critical View of the Expectation Gap. Critical Perspectives on Accounting, 3, 109-136. https://doi.org/10.1016/1045-2354(92)90007-E

[13] Godsell, D. (1992) Legal Liability and the Audit Expectation Gap. Singapore Accountant, 8, 25-28.

[14] Monroe, G.S. and Woodliff, D. (1993) The Effect of Education on the Audit Expectation Gap. Accounting and Finance, 33, 61-78. https://doi.org/10.1111/j.1467-629X.1993.tb00195.x

[15] Epstein, M.J. and Geiger, M. (1994) Investor Views of Audit Assurance: Recent Evidence of the Expectation Gap. Journal of Accountancy, 177, 60-66.

[16] Liggio, C.D. (1974) The Expectation Gap: The Accountant's Waterloo. Journal of Contemporary Business, 3, 27-44.

[17] Sikka, P.N., Puxty, T., Willmott, H. and Cooper, C. (1992) Eliminating the Expectations Gap? ACCA Research Report, No. 28, London.

[18] Giacomino, D.E. (1994) Expanding the Auditor's Role to Narrow the Expectation Gap. Business Forum, 17, 295-331.

[19] Humphrey, C.G. (1991) Audit Expectations. In: Sherer, M. and Turley, S., Eds., Current Issues in Auditing, Paul Chapman Publishing, London, 3-21.

[20] Hayes, R.S., Schilder, A., Dassen, R. and Wallage, P. (1999) Principles of Auditing: An International Perspective. McGraw-Hill Publishing Company, London. 
[21] Porter, B.A. (1990) The Audit Expectation-Performance Gap and the Role of External Auditors in Society. PhD Unpublished Thesis, Massey University, Palmerston North.

[22] DeAngelo, L. (1981) Auditor Size and Audit Quality. Journal of Accounting and Economics, 3, 183-199. https://doi.org/10.1016/0165-4101(81)90002-1

[23] Palmrose, Z. (1988) An Analysis of Auditor Litigation and Audit Service Quality. The Accounting Review, 63, 55-73.

[24] Davidson, R.A. and Neu, D. (1993) A Note on Association between Audit Firm Size and Audit Quality. Contemporary Accounting Research, 9, 479-488. https://doi.org/10.1111/j.1911-3846.1993.tb00893.x

[25] Salehi, M. and Azary, Z. (2008) Fraud Detection and Audit Expectation Gap: Empirical Evidence from Iranian Bankers. International Journal of Business and Management, 3, 65-77. https://doi.org/10.5539/ijbm.v3n10p65

[26] Salehi, M. and Kangarlouei, S.J. (2010) An Investigation of the Effect of Audit Quality on Accrual Reliability of Listed Companies on Tehran Stock Exchange. Review of International Comparative Management, 11, 940-960.

[27] Brazel, J.F., Jones, K.L. and Zimbelman, M.F. (2009) Using Non-Financial Measures to Assess Fraud Risk. http://www.ssrn.com https://doi.org/10.2139/ssrn.886545

[28] Olofin, T.A. (1996) Criminal Liability of Auditors of Collapsed Financial Institutions. The Certified National Accountant, 6, 19-21.

[29] Agbaje, F. (1996) Nigerian Auditors and the Distressed Financial Sector. The National Accountant, 6, 36-37.

[30] Yuniarti, R. (2011) Audit Firm Size, Audit Fee and Audit Quality. Journal of Global Management, 2, 84-97.

[31] NBA Practice Note 1135 (2016) Disclosure of Audit Quality Factors. http://www.nba.nl

[32] Tepalagul, N. and Lin, L. (2015) Auditor Independence and Audit Quality: A Literature Review. Journal of Accounting, Auditing and Finance, 30, 101-121. https://doi.org/10.1177/0148558X14544505

[33] Imhoff, E.A. (1978) Employment Effects on Auditor Independence. The Accounting Review, 53, 869-881.

[34] Lennox, C. (2005) Audit Quality and Executive Officers' Affiliations with CPA Firms. Journal of Accounting and Economics, 39, 201-231. https://doi.org/10.1016/j.jacceco.2003.12.002

[35] Ye, P., Carson, E. and Simnett, R. (2011) Threats to Auditor Independence: The Impact of Relationship and Economic Bonds. Auditing: A Journal of Practice and Theory, 30, 121-148. https://doi.org/10.2308/aud.2011.30.1.121

[36] Francis, J.R. and Ke, B. (2006) Disclosure of Fees Paid to Auditors and the Market Valuation of Earnings Surprises. Review of Accounting Studies, 11, 495-523. https://doi.org/10.1007/s11142-006-9014-z

[37] Beaver, W.H. and Demski, J. (1974) The Nature of Financial Accounting Objectives: A Summary and Synthesis. Journal of Accounting Research, 12, 170-187. https://doi.org/10.2307/2490504

[38] May, R.G. and Sundem, G. (1976) Research on Accounting Policy: An Overview. Journal of Accounting Research, 51, 747-763.

[39] Gaa, J.C. (1993) The Ethical Foundations of Public Accounting. CGA-Canadian Research Foundation, Vancouver. 
[40] Adams, C.A. and Evans, R. (2004) Accountability, Completeness, Credibility and the Audit Expectation Gap. Journal of Corporate Citizenship, 14, 97-115. https://doi.org/10.9774/GLEAF.4700.2004.su.00010

[41] Joshi, A. (2003) Students' Handbook on Forensic Accounting. https://www.amazon.com

[42] Bologna, G.J. and Lindquist, J.R. (1985) Fraud Auditing and Forensic Accounting. 2nd Edition, Wiley, New York.

[43] AICPA (1993) Professional Standards. American Institute of Certified Public Accountants, New York.

[44] Zia, T.A. (2010) Development, Delivery and Dynamics of a Digital Forensics Subject. 8 th Australian Digital Forensics Conference, Perth, 30 November-2 December 2010, 175-182.

[45] Imomana, J.O., Antunes, M.T.P. and Formigoni, H. (2013) The Forensic Accounting and Corporate Fraud. Journal of Information System and Technology Management, 10, 119-144. https://doi.org/10.4301/S1807-17752013000100007

[46] Wells, J.T. (2003) The Fraud Examiner. Sleuthing Careers Bring Caps Personal and Professional Satisfaction. Association of Certified Fraud Examiners.

[47] Kleeyman, Y. (2006) A Course in Forensic Accounting. Pace, U.S.

[48] Digabriele, J.A. (2007) Fishbowl the Forensic Accountant: Are There Differences in the Views of the Relevant Skills of a Forensic Accountant among Practitioners, Academics and Users of Forensic Accounting Services? Mont Clair State University. https://doi.org/10.2139/ssrn.1522488

[49] Crawford, C.J. (2010) Can Forensic Accounting Provide the Tools to Restore Confidence in the Financial Statement Reporting Process? Journal of Business and Accounting, 3, 125-133.

[50] Gray, D. (2008) Forensic Accounting and Auditing: Compared and Contrasted to Traditional Accounting and Auditing. American Journal of Business Education, 1, 115-126. https://doi.org/10.19030/ajbe.v1i2.4630

[51] Enofe, A. and Omagbon, P. (2015) Forensic Audit and Corporate Fraud. https://www.researchgate.net/publication/299843206

[52] Apostolou, B., Hassell, J.M., Webber, S.A. and Sumner, G.E. (2001) The Relative Importance of SAS No. 82 Management Fraud Risk Factors. Behavioural Research in Accounting, 13, 1-24. https://doi.org/10.2308/bria.2001.13.1.1

[53] Krell, E. (2002) Will Forensic Accounting Go Mainstream? Business Financial Journal, 8, 30-34.

[54] Moyes, G. and Baker, C.R. (2003) Auditor's Belief about the Fraud Detection Effectiveness of Standard Audit Procedures. Journal of Forensic Accounting, 4, 199-216.

[55] Hemraj, M.B. (2004) Prevention of Corporate Scandals. Journal of Financial Crime, 11, 268-276. https://doi.org/10.1108/13590790410809202

[56] Apostolon, N. and Crumbley, L.D. (2005) Fraud Surveys: Lessons for Forensic Accounting. Journal of Forensic Accounting, 4, 103-118.

[57] Houck, M.M., Kranache, M., Morris, B., Riley Jr., R.A., et al. (2006) Forensic Accounting as an Investigative Tool. The CPA Journal, 76, 68-70.

[58] Bhasin, M. (2007) Forensic Accounting: A New Paradigm for Niche Consulting. The Chartered Accountant Journal, 1000-1010.

[59] Skousen, C.J. and Wright, C.J. (2008) Contemporaneous Risk Factors and the Prediction of Financial Statement Fraud. Journal of Forensic Accounting, 9, 37-62. 
[60] Krstic, J. (2009) The Role of Forensic Accountants in Detecting Frauds in Financial Statements. Economic and Organization, 6, 295-305.

[61] Singleton, T.W. and Singleton, A.J. (2007) Fraud Auditing and Forensic Accounting. 3rd Edition, John Wiley and Sons, New York.

[62] Islam, M.J., Rahman, M.H. and Hossan, M.T. (2011) Forensic Accounting as a Tool for Detecting Fraud and Corruption: An Empirical Study in Bangladesh. ASA University Review, 5, 77-85.

[63] Adegbie, F.F. and Fakile, S.A. (2012) Economic and Financial Crimes in Nigeria: Forensic Accounting as Antidote. British Journal of Arts and Social Sciences, 6, 37-50.

[64] Gbegi, D.O. and Adebisi, J.F. (2014) Forensic Accounting Skills and Techniques in Fraud Investigation in the Nigerian Public Sector. Mediterranean Journal of Social Sciences, 5, 243-252. https://doi.org/10.5901/mjss.2014.v5n3p243

[65] Augustine, E.A. and Uagbale-Ekatah, R.E. (2015) The Growing Relevance of Forensic Accounting as a Tool for Combating Fraud and Corruption: Nigerian Experience. Research Journal of Finance and Accounting, 5, 71-77.

[66] Amake, C.C. and Ikhatua, O.J. (2016) Forensic Accounting and Fraud Detection in Nigerian Public Sector. Igbinedion University Journal of Accounting, 2, 148-173.

[67] Rehman, A. and Hashim, F. (2018) Forensic Accounting on Corporate Governance Maturity Mediated by Internal Audit: A Conceptual Overview. Advances in Economics, Business and Management Research, 46, 161-168.

https://www.researchgate.net/publication/323712993 https://doi.org/10.2991/ebic-17.2018.26

[68] Oyedokun, G.E. (2019) Forensic Accounting: Curbing Fraudulent Activities. Association of Forensic Accounting Researchers. http://www.afars.org

[69] Chandler, R.A. and Edwards, J. (1996) Recurring Issues in Auditing: Back to Future. Accounting, Auditing and Accountability Journal, 9, 4-29.

https://doi.org/10.1108/09513579610116330 